\title{
Management Problems of Turkish Businesses in Afghanistan: The Case of Kabul and Mazarisharif
}

\author{
Jamshid Khurshid \\ Erciyes University, Kayseri/Turkey \\ Ebru Aykan \\ Erciyes University, Kayseri/Turkey \\ Applied Sciences College \\ Human Resource Management
}

\begin{abstract}
Economic, political, social and technological changes worldwide have reached to massive sizes. Together with mass communication, markets have expanded and dimensions of competition have increased accordingly. The present study was conducted to identify management problems experienced by Turkish businesses operating in Afghanistan. Besides, basic problems of Turkish businesses in Afghanistan inflicted from special conditions of Afghanistan were also identified as another objective of the present study. Within the scope of these objectives, general characteristics of Turkish businesses operating in Kabul and Mazari Sharif towns of Afghanistan were determined and basic and management problems experienced by these businesses were investigated. According the research results, basic problems of Turkish businesses were gathered under 4 factors, namely as financial problems; security and infrastructure problems; economic, legal and technical problems; bureaucratic problems. The management problems of executives of Turkish businesses were also gathered under 4 groups as of problems related to planning function; problems related to controlling function; problems related to directing function and problems related to coordinating function of management.
\end{abstract}

Key Words: Afghanistan, Turkish Businesses, Management Problems, Basic Problems, International Business

\section{INTRODUCTION}

Rapid changes and developments throughout the world oriented businesses and organizations to make international and global productions. Businesses now are spending great efforts to be successful, to keep up with new competitive environment, to have low-cost and quality production, to determine consumer preferences on time and to gain a share in new markets. The organizations left behind relevant developments or not able to take place in globalized markets are not able to compete and survive. Therefore, management functions should be well-performed to improve business size, to distribute responsibilities, to follow technological developments, complex activities and developments in control and organizational management processes, to achieve anticipated profit and to have successful transitions to future periods and to have essential regulations of business administration.

The war environment experienced since 1978 has significantly destroyed the socio-economic structure of Afghanistan. The major cities and towns with great employment problems were also destroyed in this war environment. There was a quite weak infrastructure and there wasn't a central government to set economic policies. A banking system was not also available. 
Existing commercial activities were going on beyond the national or international organizations. Following the annihilation of Taliban on 7 October 2001 by the US and UK forces (Büyükbaș, 2006, 120), UN organized a meeting in Bonn with the participation of Afghan political leaders. With the Bonn Treaty signed in this meeting, a new government was established and the doors of the country were opened to the world.

In this sense, following the annihilation of Taliban regime, Afghanistan adapted free market economy and took significant steps in creation of a regular budget of the country, preparation of National Development Draft for rebuilding and improvement strategies, preparation of National Development Budget, developing new reforms and programs in financial management system to regulate the recognition, report and inspection of all financial operations. Therefore, Afghanistan attracted the attentions of world nations and organizations from several countries initiated investments in different industries in Afghanistan. Turkish organizations are among these world organizations.

Turkish organizations have concentrated their investments in Afghan market since 2001 and Turkish investments mostly focused on construction industry. Despite the steps taken to draw investments to the country during the last two years, nation-wide security problems, bureaucratic barriers, bribery and legal structure have disquieted investors. Moving from this point and so on, the objective of the present study was set as to identify the management problems of Turkish organizations investing in different industries of Afghanistan and to identify their basic problems originated from inner and outer environments.

\section{Management and Management Functions}

\section{LITERATURE REVIEW}

Management is a business activity with others to reach a certain target (Ertürk, 2000, 6). According to another definition, it is to perform organizational activities, to produce goods and services or merchandising them by using physical, financial, human and information resources of the organization (Genç, 2010,17). In general, management is defined as a continuousprocess in which two or more people come together to realize and sustain a target and in which planning, organization, directing, coordination and controlling processes are efficiently implemented and operated (Öztekin, 2010, 18). Moving from the above definitions, management can briefly be defined as follows:

1. Management is a process.

2. Management is focused on objective-oriented activities.

3. Management is planning for proper decision-making on time and to reach desired outcomes.

4. Management is an efficient use of resources.

5. Management is an objective-oriented coordination activity for the individuals of the organization.

Management functions are handled by the first management scientist Henri Fayol as planning, organizing, directing, coordination and controlling.

Success of every business is totally dependent on efficient planning. Since specific objectives constitute the bases of management, the identification of these objectives and the ways to reach these objectives can only be determined through an efficient planning (Albayrak, 2005, 277). 
Organizing is a management function and it is among the most significant ones. It is primarily related to physical activities like production of goods and services, division of the business into departments and individual-society relations. It encompasses the activities required to form the relevant structure for the realization of an objective (Buluç, 1996, 514). The structure created through planning and organizing processes should be activated along with the objectives of thebusiness. This is done with the aid of directing function. Directing goes on as the organizational activity is going on. Directing is also called as command or execution and the objective of directing function is to provide efficient performance of the tasks assigned to employees (Tutar, 2010, 223). Coordinating is a function associating various parts of business with each other. It is a significant duty of executives since coordination allows the combination of efforts, time scheduling, sequencing of complementary activities to reach a common objective (Bahar, 2011, 190).

Controlling is the last and continuous function of management.Completion of management process is only possible with a successful control. With this function, whether or not the desired objectives were achieved or to what extend these objectives were achieved is determined. Controlling is a task performed whether or not the business activities were performed in accordance with accepted plans, given instructions and set principles (Mucuk, 2013, 171).

\section{International Business}

International businesses, among the most significant organizations in today's economic system, can be defined in different ways. For instance, international business is defined as corporations making production or commerce in one or more branch of activity not only within the nation but also in foreign countries (Ünsar, 2007, 696). According to another definition, international business is defined as an organization performing production functions and producing and marketing in different countries to provide additional profitability of the investment (Tağraf, 2002, 38).

International business activities can be divided into two categories. These are international trade and international investment (Aydın, 2007, 3). When an organization deals with import and export of goods and services, an international business then is realized. When anorganization transfers its funds to a foreign country to carry out business activities, then international investment is realized. International investments can be implemented in different fashions such as an investment through a branch totally owned by itself, as a Joint Venture with a local organization, a license business, franchising activity or as a turn-key project (Koparal, 2012, 4).

\section{Management Functions and Problems of International Businesses}

Implementation of basic management functionsin international organizations is possible with a handling of management functions in a general perspective. Planning, organizing, directing, coordination and controlling functions are provided through handling domestic and foreign activities in a general perspective (Özalp, 1986, 310).

Planning in International Businesses: Planning plays significant roles in every stage of international businesses (production, licensing, foreign production and etc.). Either being national or international, planning function is the key item for the success of management (Özalp, 1998, 112). Assessment of international opportunities and threats is the primary processes for international businesses to realize efficient planning activities (Atik, 2007, 52). Planning is a process in which activities required to achieve organizational objectives are 
identified. This process also includes information gathering activities of the businesses (Türker and Örerler, 2004, 83). With this function, information gathered about the strategies and decisions designating the objectives and policies of the organizations. Planning in businesses is directing organizational activities of the businesses to defined and recognized objectives (Türker and Örerler, 2004, 83).

Planning in international businesses is the same as planning in national businesses. However, there may be some differences and complexities since foreign cultures, laws, taxes, life standards, business methods, relations to state may be quite different from one country to another (Mace, 1986, 160).

The plans made in international businesses should be comprehensive and flexibleand take various factors into consideration. Planning should be performed by the executives of the parent company. There shouldn't be conflicts between the general plans and reginal plans. Local plans are used forthe success of general plans (Ünal, 2008, 37).

While preparing investment plans, international businesses usually invests in countries rich in raw material sources and in countries where labor costs are low and environmental legislations are flexible. Besides, international businesses carry out their activities in different countries through global networks. These businesses also plan their productions across the world (Atik, 2007, 54).

Organizing in International Businesses: Organizingis primarily related to physical activities like production of goods and services, separating the business into departments and individualcommunity relations and covers the activities to form a structure required to achieve a common objective requiring a common effort (Buluç, 1996, 514). International businesses tend to different organizations for better competition in international markets.

Organizing may create serious problems and conflicts even in parent country. The size of such conflicts may extend in international businesses.

International businesses have a planned approach while forming their organizations ranging from the management of executives of parent company to management of branches. Authority and responsibilities are identified from the board of management and general directors to lower orders. In operation of organization, initially decision-making process is implemented, then decisionsare applied and finally control of activities is performed (Özalp, 1986, 136).

The factors effecting organizational structure of international businesses can be ordered as (Özalp, 1998, 137-140); growth rates of businesses, philosophy of executives, objectives of the business, relative significance of national and international activities, authority and responsibility of the business and the regions where the business is operated.

A business intended to operate in international markets initially has to carry out some investigations. In this way, the business may be able to well-comprehend the international opportunities. International operations usually have various factors and ambiguous future. Therefore, a well organization is required for profitable international operations and to minimize the risks in hand (Özalp, 1986, 139). A business operation in more than one national market needs to change its organizational structure not to experience organizational problems. International businesses deal with activities widespread over different geographies with 
different cultures, stuff, economic and political environments. Such conflicts are not seen in a business operating in a single market. The organization formed for a business operating in national markets may not be sufficient or suitable for international businesses (Cuddy, 1986, 434).

An export branch may be an initial step to improve organizational structure of an international business when they started to exporting. Following an export branch, an international department may be opened. International businesses usually implement a functional organization, geography-based organization and product-based organization (Özalp, 1998, 169).

Directing in International Businesses: Executives of businesses dealing with international operations are faced with cultures of a foreign country or a foreign region. Therefore, they should try to understand the cultures of the countries in which they are operating, should comprehend the differences and similarities between the cultures and be sensitive to cultural differences (Atik, 2007, 60).

International businesses carry out their activities with executives from different national cultures. Despite their different cultures, they have the same perspective about the business and business relations. Executives of international businesses take similar steps like investing in promising markets and places, disposing of low-yield actives and acting rationally while creating business policies. Management of large and efficient companies today may present a cosmopolite nature. In this sense, cosmopolite sides of executives dominate. In international businesses, executives from various different parts of the world are gathered under the same roof. These executives also participate in managements under the roof of same company and have a voice in decisions (Tutar, 2000, 171).

A reality has been arisen which cannot be ignored by international businesses and countries. Together with internationalization, international differences have become dominant in international businesses. Management of cultural differences constitutes a key stone in reaching business objectives in multiple and dynamic competitive environment experienced with internationalization. The internationalization movements carry businesses from national to international dimension in one hand, require the management of individuals from different cultures on the other hand. Rapid adaptation to changes, attraction to different cultures and a common value-system play significant roles in reaching managerial success in international businesses (Atik, 2007,61). All these key issues can be implemented by executives with an international perspective and through developing local behaviors by taking the changes in each national market into consideration (Ehtiyar, 2003, 67).

Coordination in International Businesses: Coordination is the leading factor providing integrity and survival of the organization. It is an objective-oriented cooperation system and mechanism. It is to provide time scheduling, sequencing, interlocking and integration of activities. Through coordination, the executives synchronize business activities and the individuals performing these activities and keep group efforts along with a common objective (Örgev, 2008, 136).

Diversity of activities, the distance between the business units and different environmental factors influence the coordination function in international businesses. Business plans and policies are prepared by the executives of internal businesses. Executives are also responsible for coordinated performance of this plan and policies. Coordination of activities is a quite hard 
task in international businesses with quite much geographical distance from each other (Dinç, 2008, 70).

Since international activities are generally considered as extended type of national activities, the factors affecting the quantity and quality of the problems experienced in coordination can be ordered as follows (Dinç, 2008, 71):

1. Activity areas of multi-national businesses

2. Formal relations between head office and branches

3. Methods applied in selection of branch managers

4. Relative importance of national and international activities

5. Political and economic conditions of the countries where branches are located

6. Extend of responsibilities transferred to branch managers.

Controlling in International Businesses: Controlling is a quite complex process in international businesses since they are located within more than one cultural, economic, political and legal environment. The geographical distance between parent and subsidiary company, language burden, cultural differences and different perspectives may create insufficiencies in information required for controlling purposes. International businesses use various monitoring methods to control their subsidiary organizations.Frequent meetings and visits of parent company executives, subsidiary organization and regional directors and assignment of mother country citizen executives may be counted among the direct controls (Dereli, 2005, 66).

International businesses generally apply two control methods as of direct and indirect control. The primary characteristics of direct controls used by international businesses can be ordered as follows (Atik, 2007, 64):

- Face-to-face and regular meetings to keep up the activities,

- Visit to executives of subsidiary organizations to learn the existing problems from them,

- Paying special attention to qualifications of employees to be employed in abroad to turn direct control into autocontrol,

- Arranging organization structure as to act along with the directions of central administration.

In indirect controls on the other hand, monthly activity reports and every kind of information sent to central organization are used to control the activities of partner organizations (Atik, 2007, 64).

While performing controlling activities in international businesses, control factors like quality control, cost and budget control, feedback and reporting systems should be created. Besides, qualified stuff should be employed and control activities should be sustained in international level.

\section{Objective and Significance of Research}

\section{RESEARCH METHODOLOGY}

The research objective was to identify management problems of Turkish businesses operating in Afghanistan. New and rapid changes worldwide direct the companies to international and global productions. Businesses are trying to adapt themselves to new competitive environment, to make low-cost but quality productions, to identify consumer preferences on time and to get a share from these new markets. The ones left out of these developments or not 
able to globalize lose their changes of competition and survival. Considering from this perspective, management functions should be implemented in the best fashion to improve business size, distribute responsibilities, keep up with technological developments, overcome the complexities in activities, follow closely the development in control and organizational management processes, gain the anticipated profit, have successful transition to future periods and to make the regulations designated by business administration. Therefore, the basic objective of the present study was set as to identify management problems of Turkish businesses investing in Afghanistan and to identify basic problems inflicting from inner and outer environments.

In line with these objectives, management problems of Turkish businesses operating in Kabul and Mazari Sharif provinces of Afghanistan and the other problems inflicting from outer environments were investigated. With this study, it is expected that the outcomes of the present case study would provide significant contributions to both management literature and managers in Afghanistan.

Economic conditions of Afghanistan were deteriorated with invasion of USSR in 1979 and subsequent civil war. With a quite weak infrastructure, there wasn't a central government to establish economic policies and even there wasn't a banking system. Current commercial activities were being implemented exclusive of national or international organizations.

Following the annihilation of Taliban by US and UK forces on 7 October 2001(Büyükbaș, 2006, 120 ), UN held a meeting in Bonn at the end of November with the participation of Afghan political leaders. At the end of this meeting, Bonn treaty with the following articles was signed: A new government will be established; public resources will be used economically and efficiently along with the policies and targets set in development plans and programs (Freeblance, 2015, 3); a regular budget will be prepared; a National Development Draft will be prepared for rebuilding and improvement strategies; new reforms will be made in financial management system to regulate the preparation of a National Development Budget, to recognize, report and inspect all the financial operations (Deik, 2011, 2-3).

With the Bonn Treaty signed in 2001, doors of the country were opened to world and a central government was established. In this way, Afghanistan attracted the attentions of world countries and several countries initiated investments in different industries of Afghanistan. Turkish organizations are also among these businesses.

The present research is significant in that Turkish businesses investing in different industries of Afghanistan would have a chance to see their management problems and they would also see the basic problems inflicting from internal and external environments. Close and intensive relationships between Afghanistan and Turkey are also found to be significant for this study. The present study is also significant in that current outcomes would bring light into future activities of business owners, entrepreneurs, managers, in general business world, in Afghanistan.

\section{Research Universe}

Executives of Turkish businesses operating in Afghanistan constituted the universe of the present research. According to information supplied from AISA and Turkish Embassy, there are around 180 Turkish companies operating in Afghanistan. However in present study, the capital city Kabul and Mazari Sharif provinces with developed industry and where Turkish businesses are intensely populated were selected. There are about 160 Turkish businesses 
operating in these two provinces. Within the scope of the present research, questionnaires were applied to 73 of them with face-to-face interviews. Also, questionnaires were sent to 80 businesses through e-mails, but only 18 responds were received. So, of 153 questionnaires sent to Turkish businesses, 91 responds were found to be assessable. All of these 91 questionnaires were subjected to assessments.

\section{Data Gathering and Analysis Methods}

The research data was gathered through questionnaires. The questionnaires were applied to company executives. Questionnaire forms were composed of three main sections. The first section questions the demographic characteristics of executives. The second section questions the general characteristics of the businesses. The third section is composed of two parts. The first part is composed of 22 statements (gathered from the studies of Aisa (2013), Barak (2011), Zengin and Canbolat (2009)) to identify the basic problems of Turkish businesses in Afghanistan. The second part is composed of 27 statements to identify the management problems of the businesses. The statements about management problems of the businesses were gathered from the scale developed and used by Kağızman (2008). The participant agreements with the statements were assessed through 5-point likert scale. In this scale: 1=Strongly Disagree, 2=Disagree, 3=Undecided, 4=Agree, 5=Strongly Agree. Reliability coefficient of the scale for management problems was identified as Cronbach Alpha=0.828; reliability coefficient of the scale for basic problems was identified as Cronbach Alpha= 0.815.The questionnaires were applied either with face-to-face interviews or through e-mail. Business executives/authority were also called and e-mailed to increase respond rates. Of 153 questionnaires sent to Turkish businesses, 91 responds were received and assessed. Questionnaire respond rate was calculated as 56.87\%.

\section{Research Findings}

\section{Results of Factor Analysis about Basic Problems of Turkish Businesses in Afghanistan}

The scale used to identify basic problems of Turkish businesses in Afghanistan was composed of 22 statements. As a result of factor analysis, double-headed 10 statements with quite low variance $(0.40)$ were omitted from the analysis. Then, the basic problems of Turkish businesses were gathered under 4 factors (12 statements).The total explained variance was identified as 0.694. These factors were named as financial problems; security and infrastructure problems; economic, legal and technical problems; bureaucratic problems. The factor analysis results about the basic problems of Turkish businesses in Afghanistan are provided in Table 1 on next page.

Considering the basic problems of Turkish businesses in Afghanistan, it was observed that executives consider security problems, lack of sub-goods and material industry, undeveloped sub-industry and resultant increased costs as serious problems. Besides, lack of financial resources, lack of state incentives, qualified labor problems, complex legislations and resultant legal insufficiencies also negatively influence business activities. On the other hand, corruptions and bribery in public sector, unofficial pressures of official institutions and collection problems are also considered as quite significant problems by several executives. 
Table 1: Factor Analysis for Basic Problems of Turkish Businesses in Afghanistan

\begin{tabular}{|l|c|c|c|}
\hline \multicolumn{1}{|c|}{ Factors } & $\begin{array}{c}\text { Variance } \\
\text { Percentage }\end{array}$ & $\begin{array}{c}\text { Cronbach } \\
\text { Alpha }\end{array}$ & $\begin{array}{c}\text { Factor } \\
\text { Loads }\end{array}$ \\
\hline Factor 1: Financial problems & 30.243 & 0.798 & \\
\hline Lack of state incentives & & & 0.832 \\
\hline Lack of financial resources & & & 0.795 \\
\hline Insufficient equity of businesses & 16.24 & 0.706 & 0.779 \\
\hline Factor 2: Security and infrastructure problems & & & 0.834 \\
\hline Qualified labor problems, lack of qualified stuff & & 0.764 \\
\hline $\begin{array}{l}\text { Lack of intermediate goods, material sub-industry, undeveloped sub- } \\
\text { industry and resultant increased costs }\end{array}$ & & & 0.679 \\
\hline Security problems & 16.236 & 0.655 & \\
\hline Factor 3: Economic, legal and technical problems & & 0.800 \\
\hline $\begin{array}{l}\text { Lack of maintenance-repair services, lack of technical service } \\
\text { infrastructure }\end{array}$ & & & 0.738 \\
\hline Collection problems and problems in collection of credited receivable & & 0.684 \\
\hline Complex legal regulations, structural problems, legal insufficiencies & & \\
\hline Factor 4:Bureaucratic problems & 14.701 & 0.782 & 0.906 \\
\hline Lack of attention on embassy stuff, non-appropriation of entrepreneurs & & & 0.844 \\
\hline $\begin{array}{l}\text { Difficulties in passport registration and visas and different } \\
\text { implementations }\end{array}$ & & & 0.721 \\
\hline $\begin{array}{l}\text { Corruptions and bribery in public sector, unofficial pressures exerted by } \\
\text { official institutions. }\end{array}$ & & & \\
\hline \multicolumn{1}{|c|}{} & & \\
\hline
\end{tabular}

KMO=0.776 Explained Variance: $69.354 ;$ p $>0.00$, Note: Subjected to 7 iterations. Sig=0.00

\section{Results of Factor Analysis about Management Problems of Turkish Businesses in Afghanistan}

Table 2: Factor Analysis for Management Problems of Turkish Businesses in Afghanistan

\begin{tabular}{|c|c|c|c|}
\hline Factors & $\begin{array}{c}\text { Variance } \\
\text { Percentage }\end{array}$ & $\begin{array}{c}\text { Cronbach } \\
\text { Alpha }\end{array}$ & $\begin{array}{l}\text { Factor } \\
\text { Loads }\end{array}$ \\
\hline Factor 1: Problems related to planning function & 30.152 & 0.799 & \\
\hline $\begin{array}{l}\text { A detailed planning is not performed during the establishment } \\
\text { (investment) phase of the business }\end{array}$ & & & 0.792 \\
\hline Management is not carried out by professional executives & & & 0.769 \\
\hline $\begin{array}{l}\text { In planning, scientific principles are not applied to determine the best } \\
\text { choice among the alternatives }\end{array}$ & & & 0.700 \\
\hline $\begin{array}{l}\text { A planning is not performed through pre-determination of what, why, } \\
\text { when, where, who will perform an activity with which resource and cost }\end{array}$ & & & 0.697 \\
\hline Alternative plansare not developed while making the planning & & & 0.656 \\
\hline Factor 2: Problems related to controlling function & 14.747 & 0.781 & \\
\hline $\begin{array}{l}\text { An efficient communication system able to transfer actual outcomes to } \\
\text { relevant unit fully and ontime is not available }\end{array}$ & & & 0.840 \\
\hline $\begin{array}{l}\text { An efficient recoding systems able to determine the actual outcomes } \\
\text { properly and ontime is not available }\end{array}$ & & & 0.818 \\
\hline Business activities are not regularly followed up & & & 0.632 \\
\hline The standards used in controlling activities are not sufficiently developed & & & 0.623 \\
\hline Factor 3:Problems related to directing function & 10.568 & 0.722 & \\
\hline Misunderstandings arise because of unclear and uncertain order and directions & & & 0.812 \\
\hline Orders are not kept up & & & 0.719 \\
\hline Oral and written orders do not comply with each other & & & 0.685 \\
\hline Factor 4: Problems related to coordination & 9.039 & 0.661 & \\
\hline $\begin{array}{l}\text { A coordination through direct meetings among individuals responsible for } \\
\text { business activities is not available }\end{array}$ & & & 0.855 \\
\hline \multirow[t]{2}{*}{$\begin{array}{l}\text { Activities to be realized are not performed in a sequential and } \\
\text { complementary fashion }\end{array}$} & & & 0.817 \\
\hline & 64.506 & $\alpha^{2}=0.792$ & \\
\hline
\end{tabular}

KMO=0.751 Explained Variance: $64.506 ; p>0.00$, Note: Subjected to 7 iterations. 
The scale used to identify management problems was composed of 27 statements. Four factors were identified in the first factor analysis, but double-headed ones were omitted. Then, 4 factors were identified from 14 statements in the subsequent analysis. These factors were named as problems related to planning function; problems related to controlling function; problems related to directing function; problems related to coordinating function of management. Reliability of the scale used to measure management problems and factor analysis results are provided in Table 2 .

Factors loads for variables corresponding to each factor are provided in Table 2.In table, number of variables representing each factor was ordered in a descending order. Cronbach Alpha coefficients of 4 factors varied between $0.66<\alpha<0.799$. These values indicated the reliability of the scale used in factor analysis (Nunnaly, 1978, 245).

\section{Characteristics of Executives and Difference Tests on Perceived Management Problems}

According to t-test and ANOVA test, a significant difference was not identified in perceived management problems by executives based on their genders and ages, but significant differences were observed based on their educational levels and positions in their organizations (Table 3 and 4).

Table3: ANOVA table for Perceived Management Problems of Executives based on their Educational Level

\begin{tabular}{|c|c|c|c|c|c|}
\hline $\begin{array}{c}\text { Management } \\
\text { Functions }\end{array}$ & Level of Education & Mean & $\begin{array}{l}\text { Standard } \\
\text { Deviation } \\
\end{array}$ & $\mathbf{F}$ & Sig \\
\hline \multirow{4}{*}{ Planning } & Primary School & 3.667 & 0.305 & \multirow{4}{*}{3.908} & \multirow{4}{*}{0.011} \\
\hline & High School & 2.633 & 0.517 & & \\
\hline & Undergraduate & 2.498 & 0.727 & & \\
\hline & Graduate & 2.025 & 0.970 & & \\
\hline \multirow{4}{*}{ Controlling } & Primary School & 2.916 & 1.010 & \multirow{4}{*}{2.514} & \multirow{4}{*}{0.064} \\
\hline & High School & 2.312 & 0.622 & & \\
\hline & Undergraduate & 2.573 & 0.730 & & \\
\hline & Graduate & 1.937 & 0.563 & & \\
\hline \multirow{4}{*}{ Directing } & Primary School & 2.889 & 0.962 & \multirow{4}{*}{2.922} & \multirow{4}{*}{0.038} \\
\hline & High School & 2.027 & 0.658 & & \\
\hline & Undergraduate & 2.240 & 0.633 & & \\
\hline & Graduate & 1.750 & 0.427 & & \\
\hline \multirow{4}{*}{ Coordination } & Primary School & 3.500 & 0.500 & \multirow{4}{*}{1.120} & \multirow{4}{*}{0.345} \\
\hline & High School & 2.583 & 0.557 & & \\
\hline & Undergraduate & 2.860 & 0.863 & & \\
\hline & Graduate & 3.062 & 1.208 & & \\
\hline
\end{tabular}

An ANOVA test was performed to see if there is a difference in management functions of executives based on their educational level. While there was a significant difference between educational levels of executives and planning and directing functions, there were not any significant differences between educational levels of executives and controlling and coordination functions. Analysis results revealed that primary school graduated executives placed less emphasis on planning and directing functions and the executive with graduate level education placed more emphasis on these functions. 
An ANOVA test was performed to see if there is a significant difference in management functions based on position of executives (Table 4). There were significant differences in management functions of executives at different positions. Business owners placed less emphasis on planning function.

Table4: ANOVA table for Executive Emphasis Placed on Perceived Management Problems based on their Positions

\begin{tabular}{|c|c|c|c|c|c|}
\hline $\begin{array}{c}\text { Management } \\
\text { Functions }\end{array}$ & Position of Executive & Mean & $\begin{array}{l}\text { Standard } \\
\text { Deviation }\end{array}$ & $\mathbf{F}$ & Sig \\
\hline \multirow{5}{*}{ Planning } & Business Owner & 2.933 & 0.847 & \multirow{5}{*}{4.312} & \multirow{5}{*}{0.003} \\
\hline & General Director & 2.561 & 0.731 & & \\
\hline & Vice Director & 2.276 & 0.519 & & \\
\hline & International Branch Director & 2.400 & & & \\
\hline & Other & 2.185 & 0.608 & & \\
\hline \multirow{5}{*}{ Controlling } & Business Owner & 2.590 & 0.921 & \multirow{5}{*}{0.719} & \multirow{5}{*}{0.581} \\
\hline & General Director & 2.560 & 0.646 & & \\
\hline & Vice Director & 2.596 & 0.875 & & \\
\hline & International Branch Director & 2.000 & & & \\
\hline & Other & 2.322 & 0.475 & & \\
\hline \multirow{5}{*}{ Directing } & Business Owner & 2.321 & 0.734 & \multirow{5}{*}{1.916} & \multirow{5}{*}{0.115} \\
\hline & General Director & 2.320 & 0.763 & & \\
\hline & Vice Director & 1.843 & 0.350 & & \\
\hline & International Branch Director & 1.333 & & & \\
\hline & Other & 2.152 & 0.525 & & \\
\hline \multirow{5}{*}{ Coordination } & Business Owner & 2.871 & 0.909 & \multirow{5}{*}{0.519} & \multirow{5}{*}{0.722} \\
\hline & General Director & 3.071 & 0.855 & & \\
\hline & Vice Director & 2.690 & 0.879 & & \\
\hline & International Branch Director & 3.000 & & & \\
\hline & Other & 2.763 & 0.833 & & \\
\hline
\end{tabular}

\section{CONCLUSION AND RECOMMENDATIONS}

Ever-changing environmental conditions and increasing competition greatly influence the activities of businesses. Businesses operating in a global market should implement management functions in the best fashion to reach pre-determined targets, to survive in these markets, to improve efficiency and productivity, to keep up with internal and external market operations and to have successful transition into future periods. In this sense, the objective of the present research was set as to determine management problems of Turkish businesses operating and investing in Afghanistan. Besides, basic problems inflicted from special internal and external constraints of Afghanistan were also identified.

The Turkish businesses in Afghanistan usually invested in construction, furniture and accessories, education, restaurant, contract-trade, logistics, electricity and heating devices.

Basically two subject matters were focused on in this study. The first one is to identify the management problems of Turkish businesses investing in different industries of Afghanistan and the second one is to put forth the basic problems inflicting from internal and external environments. Analyses were performed to identify these problems and significant outcomes were achieved about current problems.

A factor analysis was performed to group the basic problems of Turkish businesses in Afghanistan. According to analysis, basic problems of Turkish businesses were gathered under 
four groups as of financial problems; security and infrastructure problems; economic, legal and technical problems; bureaucratic problems. Considering the factor loads, it was observed that "financial problems" was seen as the most significant problem by Turkish businesses in Afghanistan.

Current findings comply with the results of Nastoh (2015) investigating BASEL implementations and their effects in banking operations. It was indicated in that study that political instability and management changes created nation-wide financial problems.

"Security and infrastructure problems" was another factor. The variable of the factor with the greatest value was qualified labor problem and lack of qualified stuff. Therefore, investor organizations exhibited a polycentric approach and brought executives from their parent country. To overcome this problem, Afghan Embassy issues visas easily and do not present any burdens in bringing foreign workers to Afghanistan. Also, Afghan government warrants that they will provide cost advantage and increase security so much as they employ Afghan workers (Boğaziçi, 2007, 27). However, lack of trained labor is still a primary problem.

"Economic, legal and technical problems" are the third factor perceived by Turkish businesses. The variables contributed to this factor were mainly arisen from legal loopholes and lack of technical structure.

Current findings on this factor comply with the results of Wasil (2015) investigating Afghan economy and economic integrations. It was indicated in that research that besides insufficient security, infrastructure was destroyed seriously throughout out long-lasting war years and therefore foreign investors were not attracted in investing in Afghanistan and various economic problems were experienced in the country.

"Bureaucratic problems" were considered as the forth basic problem of Turkish businesses in Afghanistan. Bureaucratic burdens or the difficulties experienced in bureaucracy were perceived as a problem.

With regard to basic problems of Turkish businesses in Afghanistan, security problems, lack of sub-goods and material industry, undeveloped sub-industry and resultant increased costs were considered as serious problems. Beside these problems, insufficient financial resources, lack of state incentives, qualified labor problems, complex legislations and resultant legal insufficiencies also negatively influence the activities of businesses. On the other hand, corruptions and bribery in public sector, unofficial pressures of official institutions and collection problems are also considered as quite significant problems by several executives.

A factor analysis was performed to group management problems of Turkish businesses in Afghanistan. As a result of the analysis, 4 factors were identified and they were able to explain $64.506 \%$ of total variance. These factors were named as the problems related to planning, directing, controlling and coordination functions.

With regard to factor loads, it was observed that "the problems related to planning function" formed another factor. Planning is a process. This process is known as information gathering process of management and starts with a task, that is to say, a mission statement. Organizational mission indicates the existence reasons of the organization and designates the goods and services to be produced, customers and organizational values (Can, 2005, 87). Planning is the identification of what will be performed when, where, why and by whom. 
Considering the planning problems of the businesses, it was observed that businesses did not make plans sufficiently during the investment phase, did not develop alternative plans throughout the process constituting the bases for their activities and did not use scientific principles while finding out the best choice among the alternative plans.

"The problems related to controlling function" was perceived as the second factor by the executives. Controlling is considered as one of the strategic way of solving current problem or preventing them before they emerge (Taşkın, 2013, 294).Unavailability of an efficient communication system able to transfer actual outcomes to relevant unit fully and ontime, inefficiency of recoding systems able to determine the actual outcomes properly and ontime, irregular follow up of business activities and insufficient standards used in controlling activities were identified as the problems related to controlling function of businesses. Such problems may directly or indirectly influence the efficient operation and success of the business.

"The problems related to directing function" was considered as the third factor by the executives of Turkish businesses in Afghanistan. Directing designates continuous decisionmaking through specific or general orders or directives (Efil, 2010,155). The directing function targets the issues like successful achievement of objectives, motivation of employees, a well leadership of the manager, efficient communication systems within the organization, assigning rational task and authorities to employees based on their experience and capabilities. The problems related to directing function were identified as incompliance between oral and written orders, unviability of mutual information, data and idea exchange between the tasks to be done and the stuff to do these tasks, non-follow up of orders.

"The problems related to coordination function" was identified as the factor. Coordination mainly is a function of senior executives. The coordination problems were mainly resulted from deficiencies in combining, time scheduling and sequencing of activities and complementing each other (Taşkın, 2013, 270). There was a compliance problem between the business and the employees.

The t-test and ANOVA results revealed that gender and age of executives did not have significant effects on perceived management problems, but their educational levels and positions in organization had significant effects on perceived management problems.

An ANOVA test was performed to see if there is a significant difference in management functions of executives based on their educational levels. Test results revealed significant differences between educational level and planning and directing functions, but insignificant differences were observed between educational level and controlling and coordinating functions. While primary school-graduated managers placed less emphasis on planning and directing functions, the executives with graduate level education placed more emphasis on these two functions.

An ANOVA test was also performed to check if there is a significant difference in management functions of executives based on their position within the organization. There were significant differences in planning function of executives based on their position. Business owners placed less emphasis on planning functions.

As to conclude, it can be stated that the problems related to management functions of Turkish businesses in Afghanistan were influenced by close or further environment of the businesses. Financial problems of Afghanistan, security and infrastructure problems, economic, legal and 
technical problems, bureaucratic problems, lack of state incentives, insufficient sub-goods and material industry, undeveloped sub-industry, lack of qualified labor, corruption and bribery in public sector, unofficial pressure of official institutions, insufficiency of organizations in motivating their executives all influenced the performance of Turkish businesses and made difficult to focus on their own business and to propose solutions for current problems. To overcome these problems, central coordination organization should be well managed, security and infrastructure problems should be eliminated, corruptions and bribery in public sector and unofficial pressures of official institutions should be prevented, sub-industry should be developed, state incentives and credits should be supplied. Besides, further research should be carried out on business administration and management functions.

Along with these conclusions, following recommendations were developed about the problems of Turkish businesses operating in Afghanistan:

- The executives of Turkish businesses in Afghanistan should improve their knowledge and experience on planning, program development and controlling issues and all activities should be performed along with a plan.

- Internal and external environmental constraints like infrastructure, raw material, energy, qualified labor and technology should be taken into consideration and organizational structure should be formed.

- Along with the objectives, corporation, communication and coordination among the employees should be developed.

- Activities, outcomes and implementation reports should be subjected to internal and external audits and a tool improving efficiency and productivity should be used.

- Regular surveys should be carried out within the organization to identify potential sources of management problems of Turkish businesses in Afghanistan and improvements should be made based on survey results.

Only a situation assessment was performed in this study. In further studies, the effects of problems indicated in present study may be investigated and detailed investigations about each one of management functions can be carried out for Turkish businesses investing in Afghanistan.

The present outcomes may have significant contributions to management literature. There were not any studies on this issue carried out in Turkey and Afghanistan. Therefore, such a case increased the significance of present situation assessment. It should be kept in mind that there is a need for further studies to generalize the current outcomes. It was thought that the information gathered through focusing on this issue will be quite beneficial for executives and other researchers.

\section{References}

Albayrak, Burhan (2005). Proje Yönetimi. Ankara: Nobel Yayınevi.

Aydın, A. H. (2007). Uluslararası İşletmeciliğe Giriş. Editör: İnan ÖZALP. Uluslararası İşletmecilik. Eskişehir: Anadolu Üniversitesi Yayını.

Bahar, Emel (2011). İşletme Yönetimi. İstanbul: Beta Yayınevi.

Can, Halil (2005). Organizasyon ve Yönetim. Ankara: Siyasal Kitabevi.

Cuddy, D. J. (1986). Uluslararası Faaliyetlerin Planlanması ve Denetimi. Derleyen; İnan ÖZALP. Uluslararası İşletmecilik (Seçme Yazılar). Eskişehir: T.C. Anadolu Üniversitesi Yayınları.

Efil, İsmail (2010)., İşletmelerde, Yönetim ve Organizasyon (11.Baskı). Bursa: Dora Yayın-Basım Ltd.Ştl. 
Ertürk, Mümin (2000). İşletmelerde Yönetim ve Organizasyon (2.Baskı). İstanbul: Beta Yayınevi.

Genç, Nurullah (2010). Meslek Yüksek Okulları İçin Yönetim ve Organizasyon. Ankara: Seçkin Yayıncılık.

Koparal, Celil (2012). Uluslararası İşletmeciliğe Giriş. Editör: İnan ÖZALP. Uluslararası İşletmecilik. Eekişehir: Anadolu Üniversitesi Yayını.

Mace, Myles L. (1986). Genel Müdür ve Uluslararası Faaliyetler. Derleyen; İnan ÖZALP. Uluslararası İşletmecilik (Seçme Yazılar). Eskişehir: T.C. Anadolu Üniversitesi Yayınları.

Mankan, Esra (2013). Yönetim ve Organizasyon. İzmir: İlya Yayınevi.

Mucuk, İsmet (2013). Modern İşletmecilik (18.Baskı). İstanbul: Türkmen Kitabevi

Nunnaly, J. C. (1978). Psychometric Theory (2.th ed.). New York: McGraw-Hill.

Örgev, M., (2008). Koordinasyon. Editörler: C. AYDEN ve M. ÖRGEV. Yönetim ve organizasyon. İstanbul: Lisans Yayıncilık.

Özalp, İnan (1998). Çokuluslu İşletmeler: Uluslararası Yaklaşım. Eskişehir: T. C. Anadolu Üniversitesi yayınları.

Özalp, İnan (1986). Uluslararası İşletmecilik. Eskişehir: T. C. Anadolu Üniversitesi yayınları.

Öztekin, Ali (2010). Yönetim Bilimi (4.Baskı). Ankara: Siyasal Kitabevi.

Taşkın, Erdoğan (2013). İşletme Yönetimi İlkeleri. Ankara: Nobel Yayınevi.

Tutar, Hasan (2010). İşletme Yönetimi. Ankara: Seçkin Yayınevi.

Tutar, Hasan (2000). Küreselleşme Sürecinde İşletme Yönetimi. İstanbul: Hayat Yayınevi.

Makaleler :

Aisa, (2013). "Ravendi Sermaye Guzari Der Afganistan: Çalışha ve Muşavikha”. Kabil: Afghanistan Investment Support Agency.

Atik, Sinan (2007). Küreselleşme ve Küresel İşletmeler. İstanbul: T.C. Kadir Has Üniversitesi Sosyal Bilimler Enstitüsü İşletme Anabilim Dali, Basılmamış Yüksek Lisans Tezi

Barak, O., (2011). Kazakistan'da Yerleşik Türk Firmalarının Yapısı ve Geleceğe İlişkin Öngörü ve Öneriler. Çankırı: Orta Asya Ekonomileri III.

Boğaziçi İşadamları Derneği (2004). Afganistan Ülke Raporu.

www.bogazici.org.tr/.../afganistan_raporu_nisanS.pdf (Erişim Tarihi: 18.7.2015).

Buluç, B. (1996). “Yönetımde Örgütleme Sürecı”. Eğitim Yönetimi, Yıl 2, Sayı 4, Güz 1996, s.s.513-522.

Büyükbaş, M. (2006). Amerika Birleşik Devletleri'nin Afganistan'a Müdahalesi ve Afganistan'da Oluşturulan Yeni Yönetim Yapısı. Süleyman Demirel Üniversitesi Sosyal Bilimler Enstitüsü Kamu Yönetimi Ana Bilim Dali, Basılmamış Yüksek Lisans Tezi.

Deik (2011). Afganistan Ülke Bülteni. https://www.deik.org.tr/Contents/FileAction/2735 (Erişim Tarihi: 13.7.2015).

Dereli, Beliz (2005). Çokuluslu İşletmelerde İnsan Kaynakları Yönetimi. İstanbul Ticaret Üniversitesi Sosyal Bilimler Dergisi Yıl:4 Sayı:7 Bahar 2005/1 s.59-81

Dinç, Hakan (2008). Çokuluslu İşletmelerin Organizasyonu, Organizasyon Sorunları ve Bir Uygulama. İstanbul: TC Yıldız Teknik Üniversitesi Sosyal Bilimler Enstitüsü İşletme Anabilimdalı İşletme Yönetimi Yüksek Lisans Programı, Basılmamış Yüksek Lisans Tezi

Ehtiyor, Rüya: “Kültürel Sinerji: Uluslararası İşletmelere Yönelik Kavramsal Bir İrdeleme”. Antalya: Akdeniz Üniversitesi İİBF Dergisi, Cilt:3, Sayı:5, 2003, (66-78)

Kağızman, H. B. (2008). Türkiye'deki Teknoparklarda Faaliyet Gösteren İşletmelerin Yönetsel Sorunları. Ankara: Gazi Ün. Eğitim Bilimleri Enstitüsü İşletme Eğitimi Anabilim Dalı. Basılmamış Yüksek Lisans Tezi.

Nastoh, J. H., (2015). Afganistan Bankacılık Sektöründe Basel Uygulamaları ve Etkilerinin İncelenmesi. Ankara: Gazi Üniversitesi Sosyal Bilimler Enstitüsü İşletme Anabilim Dalı, Basılmamış Yüksek Lisans Tezi

Tağraf, Hasan (2002). Küreselleşme Süreci ve Çokuluslu İşletmelerin Küreselleşme Sürecine Etkisi. C.Ü. İktisadi ve İdari Bilimler Dergisi, Cilt 3, Sayı 2, 2002 
Türker, M. ve E. O. Örerler (2004). Türk Şirketlerinin Küresel Şirket Haline Getirilmesi Yolları. İstanbul: İstanbul Ticaret Odası yayınları. Yayın No. 2004-60

Ünal, Pınar (2008). Uluslararası İnsan Kaynakları Yönetimi. İstanbul Teknik Üniversitesi, Fen Bilimleri Enstitüsü, Endüstri Mühendisliği Anabilim Dalı, Basılmamış Yüksek Lisans Tezi

Ünsar, Sinan (2007). Uluslararası İşletmelerde Üretim Stratejileri. Journal of Yasar University, 2(7), 695-708

Wasıl, M. R. (2015). Afganistan Ekonomisi ve Ekonomik Entegrasyonlar (Eco) Örneği. Ankara: Gazi Üniversitesi Sosyal Bilimler Enstitüsü İktisat Anabilim Dalı. Basılmamış Yüksek Lisans Tezi

Zengin, E. ve Y. B. CANBOLAT (2009). “Azerbaycan'da Bulunan Türk İşletmelerinin Yapıları ve Sorunları”. Qafqaz Ünivesitesi, İktisadi ve İdari Bilimler Fakültesi, Kamu Yönetimi Bölümü. 